\title{
Penerapan Supervisi Klinis untuk Meningkatkan Kinerja Guru dalam Proses Belajar Mengajar Gugus IV Sanankulon
}

\author{
Sri Utami \\ UPTD Pendidikan Kecamatan Sanankulon \\ Email: asriabadi05@gmail.com
}

\section{Tersedia Online di \\ http://www.jurnal.unublitar.ac.id/ index.php/briliant}

\section{Sejarah Artikel}

Diterima pada 16 Juni 2017

Disetuji pada 23 Juni 2017

Dipublikasikan pada: 2 Agustus 2017 Hal 272-280

\section{Kata Kunci:}

Kinerja guru, supervisi klinis

\begin{abstract}
Abstrak: Tujuan penelitian untuk mengetahui dampak supervise klinis terhadap kinerja guru dalam proses belajar mengajar.Tindakan melalui supervise klinis.Hasil penelitian menunjukkan adanya peningkatan kinerja guru dalam melaksanakan proses belajar mengajar, siklus I mencapai $72 \%$ atau ada13 guru dari 18 guru sudah berhasil dalam melaksanakan proses belajar mengajar, siklus II keberhasilan guru dalam melaksanakan proses belajar mengajar mencapai $89 \%$ atau ada 16 guru dari 18 guru sudah berhasil dalam melaksanakan proses belajar mengajar.
\end{abstract}

Guru mempunyai peranan yang sangat penting dalam pelaksanaan proses pembelajaran, karena guru merupakan "key person" yang berhadapan langsung dengan siswa dalam kegiatan proses belajar mengajar. Guru harus dapat menciptakan suasana yang kondusif agar siswa bersedia terlibat sepenuhnya pada kegiatan pembelajaran, sehingga tujuan pembelajaran yang telah ditetapkan dapat dicapai secara efektif dan efisien.

Mengingat begitu pentingnya peranan guru dalam menentukan keberhasilan pembelajaran tersebut, maka guru dituntut memiliki kinerja yang tinggi, yaitu seperangkat kemampuan kerja/unjuk kerja guru dalam menjalankan tugas-tugasnya, terutama dalam melaksanakan kegiatan-kegiatan yang berhubungan dengan proses belajar mengajar secara profesional sesuai etika profesi keguruan.

Kinerja guru sangat berhubungan dengan kemampuan dan motivasi dalam menjalankan tugas-tugasnya dengan baik dan benar. Kemampuan dan motivasi guru dalam menjalankan tugasnya tersebut dapat diperoleh melalui suatu pembinaan khusus sesuai kualifikasi yang diharapkan, baik internal maupun eksternal.

Dalam sebuah lingkup pendidikan, pengawas dan kepala sekolah perlu memberikan perhatian secara sungguh-sungguh terhadap usaha-usaha mendayagunakan, memajukan dan meningkatkan kinerja guru di sekolah secara terus menerus. Orientasi dari pembinaan kepala sekolah ini diarahkan pada peningkatan kinerja guru yang meliputi: pertumbuhan keilmuan, wawasan berpikir, sikap terhadap pekerjaan dan keterampilan guru dalam melaksanakan tugas. Sebagaimana disebutkan dalam UU Nomor 20 Tahun 2003 BAB XI yang menyebutkan bahwa Pendidik merupakan tenaga profesional yang bertugas merencanakan dan melaksanakan proses pembelajaran, menilai hasil pembelajaran, melakukan pembimbingan dan pelatihan, serta melakukan 
penelitian dan pengabdian kepada masyarakat, terutama bagi pendidik dan perguruan tinggi.

Pada dasarnya peningkatan kualitas diri seorang guru harus menjadi tanggung jawab diri sendiri. Oleh karenanya usaha peningkatan kualitas guru terletak pada diri guru sendiri. Hal tersebut perlu adanya kesadaran pada diri guru untuk senantiasa dan secara terus menerus meningkatkan pengetahuan dan kemamuan yang dipelukan guna peningkatan kualitas kerja sebagai pengajar profesional. (Hamid Darmadi, 2009:13).

Kesadaran ini akan timbul dan berkembang sejalan dengan kemungkinkan pengembangan kinerja guru. Oleh karena itu pengembangan kualitas guru sangat berkaitan dengan kinerja dalam meningkatkan motivasi dan prestasi belajar siswa sehingga terwujudnya tujuan pendidikan nasional yaitu mencerdaskan kehidupan bangsa. Keberhasilan dalam mencapai tujuan pendidikan tidak terlepas dari peran serta seorang guru, karena guru merupakan subyektifitas sentral di dalam pembelajaran. Sebagaimana disebutkan Hamid Darmadi (2009:59) yang menyebutkan bahwa: Guru adalah kondisi yang diposisikan sebagai garda terdepan dan posisi sentral di dalam pelaksanaan proses pembelajaran. Berkaitan dengan itu, maka guru akan menjadi bahan pembicaraan banyak orang, dan tentunya tidak lain berkaitan dengan kinerja dan totalitas dedikasi dan loyalitas pengabdiannya".

Untuk memainkan peranan dan melaksanakan tugas-tugas itu, seorang guru diharapkan memiliki kemampuan professional yang tinggi. Dalam hubungan ini, maka untuk mengenal peserta didik dengan baik, guru perlu memiliki kemampuan untuk melakukan diagnosis serta mengenal dengan baik cara-cara yang paling efektif untuk membantu peserta didik tumbuh sesuai dengan potensinya masing-masing serta selalu memberikan inovasi baru dalam dunia pendidikan.

Dinn Wahyudin (2006:8.3) berpendapat bahwa: Dalam bidang pendidikan inovasi perlu terus dilakukan, karena pendidikan tidak telepas dari perubahan yang terjadi di masyarakat yang melingkupinya. Dalam bidang pendidikan kegiatan inovasi perlu ditingkatkan terus-menerus dalam rangka memenuhi tuntutan perubahan dan perkembngan yang terjadi di masyarakat luas.

Dalam melakukan inovasi terhadap kegiatan pembelajaran, maka seorang guru tidak boleh terpaku pada metode pembelajaran ceramah, tetapi harus mampu memberi dasar-dasar pengetahuan, kemampuan, kreativitas sesuai dengan kemampuan peserta didik. Sebagaimana pendapat Moeslichatoen (2004 : 4) yang menyatakan bahwa: Dalam rangka meletakkan dasar ke arah perkembangan sikap, pengetahuan, keterampilan, dan daya cipta anak didik, guru perlu memahmi kemampuan-kemampuan apa yang hrus dikuasai anak didik.

Hal inilah yang mendasari pemerintah untuk mewujudkan tujuan dalam memperbaiki sistem pendidikan nasional, salah satunya melalui pembahruan Kurikulum Berbasis Kompetensi (KBK) menjadi Kurikulum Tingkat Satuan Pendidikan (KTSP). Dalam KTSP terlihat bahwa guru hanya sebagai mediator dan pemberi penguatan dalam pembelajaran dan lebih menekankan pada peran aktif anak dalam proses pembelajaran.

Berdasarkan observasi awal di Gugus IV Kecamatan Sanankulon Kabupaten Blitar yang terdiri dari 6 lembaga sekolah tingkat dasar, proses belajar mengajar yang dilakukan guru masih perlu ditingkatkan karena sebagian besar 
guru masih membuat penafsiran ganda dalam merumuskan tujuan pembelajaran. Guru kurang memperhatikan alokasi waktu dalam penyusunan rencana pelaksanaan pembelajaran. Pelaksanaan pembelajaran yang dilakukan masih belum mengaitkan materi dengan realitas kehidupan nyata. Evaluasi yang diberikan tidak menggunakan rubrik penilaian yang tepat.

Berdasarkan keadaan tersebut di atas, maka diperlukan suatu mekanisme supervisi terhadap lembaga sekolah. Supervisi tersebut melibat peran seorang supervisor yang bertugas dalam melakukan tugas supervisi sekolah yang bersangkutan. Terdapat empat macam peran seorang pengawas atau supervisor pendidikan, yaitu sebagai: coordinator, consultant, group leader dan evaluator. Supervisor harus mampu mengkoordinasikan programs, goups, materials, and reports yang berkaitan dengan sekolah dan para guru. Supervisor juga harus mampu berperan sebagai konsultan dalam manajemen sekolah, pengembangan kurikulum, teknologi pembelajaran, dan pengembangan staf.

Untuk memecahkan masalah ini peneliti selaku pengawas di daerah binaan Gugus IV Kecamatan Sanankulon Kabupaten Blitar melakukan penelitian supervisi klinis guna meningkatkan kinerja guru dalam proses belajar mengajar. Diharapkan penelitian ini bermanfaat sebagai acuan guna meningkatkan kinerja guru dalam proses belajar mengajar Diharapkan penelitian ini bermanfaat untuk meningkatkan mutu di lembaga pendidikan

\section{METODE}

Tempat yang digunakan dalam penelitian tindakan sekolah ini di Gugus IV Kecamatan Sanankulon Kabupaten Blitar yang terdiri dari 6 SD negeri yaitu SDN Sumberjo 01, SDN Sumberjo 02, SDN Gledug 01, SDN Gledug 02, SDN Jeding, dan SD Alam Wanatani

Penelitian ini dilakukan selama tiga bulan dari bulan Februari sampai dengan April 2014, mulai dari persiapan sampai dengan pelaporan sebagaimana tersebut dalam jadwal berikut ini:

Tabel 1. Jadwal Penelitian

\begin{tabular}{|l|l|l|}
\hline No & Kegiatan & Waktu \\
\hline 1. & Persiapan & $15-02-2014$ \\
\hline 2. & Pelaksanaan Siklus I & $08-03-2014$ \\
\hline 3. & Pelaksanaan Siklus II & $22-03-2014$ \\
\hline 4. & Pelaporan & $26-04-2014$ \\
\hline
\end{tabular}

Teknik pengumpulan data yang penulis lakukan adalah dengan melakukan pengamatan sekaligus melakukan penilaian selama kegiatan supervisi berlangsung dalam setiap siklusnya. Pengamatan yang dikumpulkan berupa kinerja guru dalam melakukan kegiatan proses belajar mengajar yang meliputi aspek rencana pelaksanaan pembelajaran, pelaksanaan pembelajaran, dan evaluasi pembelajaran.

Dalam penelitian ini peneliti menggunakan lembar pengamatan dan penilaian untuk mengamati serta menilai kinerja guru selama proses supervisi berlangsung. 
Penskoran dan Penilaian

Jumlah Skor $=$ Perencanan + Pelaksanaan + evaluasi

Nilai $=$ Jumlah Skor yang diperoleh $\mathrm{x} 10$

Rumus prosentase keberhasilan guru dalam melaksanakan pembelajaran

$$
\frac{\text { Jumlah guru yang berhasil }}{\text { Jumlah seluruh guru }} \times 100 \%
$$

Dalam penelitian ini, penulis membuat sebuah standarisasi keberhasilan seorang guru dalam melaksanakan proses belajar mengajar apabila mencapai nilai $>=70$, sedangkan untuk tingkat klasikal minimal mencapai $85 \%$.

Penelitian ini dilakukan dalam dua siklus terdiri dari atas empat langkah, yaitu perencanaan (planning), aksi atau tindakan (acting), observasi (observing), dan refleksi (reflekting).

Alur Penelitian Tindakan Sekolah (1) Dari identifikasi masalah yang ada, dibuatlah sebuah perecanaan awal, sebelum mengadakan tindakan penelitian, penulis menyusun rumusan masalah, tujuan dan membuat rencana tindakan yang di dalamnya terdapat instrumen penelitian dan perangkat pembelajaran. (2) Setelah perencanaan dilakukan, penulis mengadakan sebuah tindakan yang digunakan untuk meningkatkan kinerja guru di Gugus IV Kecamatan Sanankulon Kabupaten Blitar dalam proses belajar mengajar melalui supervisi klinis. (2) Dari hasil tindakan sekolah, penulis melakukan observasi dari segala bentuk kinerja guru dan mencatat dalam kriteria pengamatan dan penilaian dengan menggunakan format yang telah dipersiapkan. (3) Dari hasil observasi yang diperoleh, penulis melakukan refleksi. Dalam kegiatan ini, penulis menyimpulkan pelaksanaan proses belajar mengajar sebagai kinerja guru. (4) Dari hasil refleksi, penulis membuat perencanaan kembali untuk mengatasi kekurangan yang terjadi pada siklus I. Dari hasil perencanaan ini diharapkan terjadi peningkatkan kinerja guru dalam melaksanakan proses belajar mengajar dengan mengedepankan tugas utama guru yaitu merencanakan, melaksanakan pembelajaran, dan memberikan evaluasi.

\section{HASIL}

\section{Siklus I}

Dari hasil pengamatan terhadap kinerja guru yang berjumlah 18 guru dengan menggunakan kriteria penilaian yang telah disiapkan, diperoleh data sebagai berikut :

Tabel 2 Hasil rekapitulasi penilaian kinerja guru dalam proses pembelajaran pada siklus I

\begin{tabular}{|c|c|c|c|c|c|c|c|}
\hline \multirow[b]{2}{*}{ No } & \multirow[b]{2}{*}{ Nama } & \multicolumn{3}{|c|}{ Skor } & \multirow[b]{2}{*}{$\begin{array}{l}\text { Jml } \\
\text { Skor }\end{array}$} & \multirow[b]{2}{*}{ Nilai } & \multirow[b]{2}{*}{ Ket } \\
\hline & & \begin{tabular}{|c} 
Pe- \\
rencanaan \\
Pem- \\
belajaran
\end{tabular} & $\begin{array}{l}\text { Pelaksanaan } \\
\text { Pem-belajaran }\end{array}$ & $\begin{array}{c}\text { Evaluasi } \\
\text { Pem- } \\
\text { belajaran }\end{array}$ & & & \\
\hline 1. & Saropah, S.Pd & 83 & 78 & 60 & 221 & 74 & $\mathrm{~B}$ \\
\hline 2. & Mujiati, S.Pd & 83 & 78 & 63 & 224 & 75 & B \\
\hline
\end{tabular}

275 BRILIANT: Jurnal Riset dan Konseptual Volume 2 Nomor 3, Agustus 2017 


\begin{tabular}{|r|l|c|c|c|c|c|l|}
\hline \multirow{2}{*}{ No } & \multicolumn{1}{|c|}{ Nama } & $\begin{array}{c}\text { Sk- } \\
\text { rencanaan } \\
\text { Pem- } \\
\text { belajaran }\end{array}$ & $\begin{array}{c}\text { Pelaksanaan } \\
\text { Pem-belajaran }\end{array}$ & $\begin{array}{c}\text { Evaluasi } \\
\text { Pem- } \\
\text { belajaran }\end{array}$ & $\begin{array}{c}\text { Jml } \\
\text { Skor }\end{array}$ & Nilai & Ket \\
\hline 3. & Suminto, S.Pd & 85 & 80 & 65 & 230 & 77 & B \\
\hline 4. & Nuryasin, S.Pd & 85 & 75 & 60 & 220 & 73 & B \\
\hline 5. & Lia N, S.Pd & 83 & 79 & 65 & 227 & 76 & B \\
\hline 6. & Sri Nuzula, S.Pd & 70 & 68 & 60 & 198 & 66 & BB \\
\hline 7. & Dra. Indiah & 83 & 75 & 63 & 221 & 74 & B \\
\hline 8. & Sriandayani, S.Pd & 83 & 75 & 63 & 221 & 74 & B \\
\hline 9. & Siswadii, S.Pd & 83 & 78 & 68 & 229 & 76 & B \\
\hline 10. & Indarwati, S.Pd & 83 & 78 & 65 & 226 & 75 & B \\
\hline 11. & Yuniastuti,S.Pd & 70 & 68 & 60 & 198 & 66 & BB \\
\hline 12. & Siti M,S.Pd & 83 & 78 & 63 & 224 & 75 & B \\
\hline 13. & Heriyati,S.Pd & 70 & 68 & 60 & 198 & 66 & BB \\
\hline 14. & Bambang W,S.Pd & 70 & 68 & 60 & 198 & 66 & BB \\
\hline 15. & Rukmiasih,S.Pd & 68 & 68 & 63 & 199 & 66 & BB \\
\hline 16. & Sulistyowati,S.Pd & 80 & 78 & 65 & 223 & 74 & B \\
\hline 17. & Yuyun M,S.Pd & 80 & 78 & 65 & 223 & 74 & B \\
\hline 18. & Khanifah,S.Pd & 83 & 80 & 68 & 231 & 77 & B \\
\hline Guru yang berhasil & & & & & 13 & \\
\hline Guru yang belum berhasil & & & & 5 & \\
\hline Prosentase keberhasilan & & & & & $72 \%$ & \\
\hline
\end{tabular}

Keterangan :

$\mathrm{B}=$ Berhasil

$\mathrm{BB}=$ Belum Berhasil

Dari tabel hasil penilaian di atas dapat dijelaskan bahwa dengan melakukan supervisi model klinis yang ada di Gugus IV Kecamatan Sanankulon pada siklus I diperoleh keberhasilan guru dalam melaksanakan proses belajar mengajar dengan mengedepankan tugas utama guru mencapai $72 \%$ atau ada 13 guru dari 18 guru sudah berhasil dalam melaksanakan proses belajar mengajar. Hasil tersebut menunjukkan bahwa pada siklus pertama secara klasikal, guru belum berhasil. Hal ini disebabkan karena guru yang memperoleh nilai $\geq 70$ hanya sebesar $72 \%$. Pencapaian keberhasilan ini lebih kecil dari persentase ketuntasan yang dikehendaki yaitu sebesar $85 \%$.

\section{Siklus II}

Dari hasil pengamatan terhadap kinerja guru yang berjumlah 18 guru dengan menggunakan kriteria penilaian yang telah disiapkan, diperoleh data sebagai berikut : 
Tabel 3 Hasil rekapitulasi penilaian kinerja guru dalam proses pembelajaran pada siklus II

\begin{tabular}{|r|l|c|c|c|c|c|l|}
\hline \multirow{2}{*}{ No } & \multicolumn{1}{|c|}{ Nama } & $\begin{array}{c}\text { Skor } \\
\text { rencanaan } \\
\text { Pem- } \\
\text { belajaran }\end{array}$ & $\begin{array}{c}\text { Pelaksanaan } \\
\text { Pem- } \\
\text { belajaran }\end{array}$ & $\begin{array}{c}\text { Evaluasi } \\
\text { Pem- } \\
\text { belajaran }\end{array}$ & $\begin{array}{c}\text { Jml } \\
\text { Skor }\end{array}$ & Nilai & Ket \\
\hline 1. & Saropah, S.Pd & 85 & 82 & 73 & 240 & 80 & B \\
\hline 2. & Mujiati, S.Pd & 83 & 79 & 68 & 230 & 77 & B \\
\hline 3. & Suminto, S.Pd & 93 & 81 & 70 & 244 & 81 & B \\
\hline 4. & Nuryasin, S.Pd & 95 & 82 & 75 & 252 & 84 & B \\
\hline 5. & Lia N, S.Pd & 90 & 79 & 73 & 242 & 81 & B \\
\hline 6. & Sri Nuzula, S.Pd & 95 & 83 & 70 & 248 & 83 & B \\
\hline 7. & Dra. Indiah, S.Pd & 90 & 81 & 70 & 241 & 80 & B \\
\hline 8. & Sriandayani, S.Pd & 90 & 81 & 70 & 241 & 80 & B \\
\hline 9. & Siswadi, S.Pd & 88 & 79 & 73 & 240 & 80 & B \\
\hline 10. & Indarwati, S.Pd & 90 & 83 & 68 & 241 & 80 & B \\
\hline 11. & Yuniastuti,S.Pd & 70 & 68 & 65 & 203 & 68 & BB \\
\hline 12. & Siti M,S.Pd & 90 & 80 & 73 & 243 & 81 & B \\
\hline 13. & Heriyati,S.Pd & 70 & 68 & 65 & 203 & 68 & BB \\
\hline 14. & Bambang W,S.Pd & 90 & 83 & 65 & 238 & 79 & B \\
\hline 15. & Rukmiasih,S.Pd & 75 & 70 & 70 & 215 & 72 & B \\
\hline 16. & Sulistyowati,S.Pd & 88 & 79 & 68 & 235 & 78 & B \\
\hline 17. & Yuyun M,S.Pd & 88 & 79 & 68 & 235 & 78 & B \\
\hline 18. & Khanifah,S.Pd & 88 & 83 & 73 & 244 & 81 & B \\
\hline Guru yang berhasil & & & & & 16 & \\
\hline Guru yang belum berhasil & & & & & 2 & \\
\hline Prosentase keberhasilan & & & & & $89 \%$ & \\
\hline
\end{tabular}

Keterangan:

$\begin{array}{ll}\mathrm{B} & =\text { Berhasil } \\ \mathrm{BB} & =\text { Belum Berhasil }\end{array}$

Dari tabel hasil penilaian di atas dapat dijelaskan bahwa dengan melakukan supervisi model klinis yang ada di Gugus IV Kecamatan Sanankulon pada siklus I diperoleh keberhasilan guru dalam melaksanakan proses belajar mengajar dengan mengedepankan tugas utama guru mencapai 89\% atau ada 16 guru dari 18 guru sudah berhasil dalam melaksanakan proses belajar mengajar. Hasil tersebut menunjukkan bahwa pada siklus kedua secara klasikal, guru sudah berhasil. Hal ini disebabkan karena guru yang memperoleh nilai $\geq 70$ sudah memenuhi prosentase keberhasilan yang diharapkan yaitu $85 \%$. 


\section{PEMBAHASAN}

Dalam penelitian ini, peneliti menggunakan supervisi klinis untuk meningkatkan kinerja guru dalam kegiatan proses belajar mengajar dengan mengedepankan tugas utama guru yaitu merencanakan, melaksanakan pembelajaran, dan memberikan evaluasi terhadap aktivitas kegiatan pembelajaran di Gugus IV Kecamatan Sanankulon Kabupaten Blitar.

\section{Deskripsi Supervisi Akademik klinis untuk meningkatkan kinerja guru dalam proses belajar mengajar dengan mengedepankan tugas utama guru.}

Pada awal pelaksanaan supervisi akademik model klinis pada peningkatan kinerja guru dalam proses belajar mengajar tergolong belum maksimal. Hal ini disebabkan karena guru kurang mampu mengelola waktu sesuai dengan alokasi waktu yang telah ditetapkan dalam perencanaan pelaksanaan pembelajaran. Selain itu guru belum membuat rubrik penilaian dalam pemberian evaluasi pembelajarn. Namun dengan adanya supervisi klinis ini membuat guru terlihat termotivasi untuk melakukan inovasi dalam proses belajar mengajar baik dalam perencanaan, pelaksanan, maupun pemberian evaluasi.

Pada kegiatan siklus kedua, aktivitas kegiatan proses belajar mengajar guru menunjukkan adanya peningkatan. Hal ini terlihat dengan kelengkapan perencanan pembelajaran yang dipersiapkan, pelaksanaan pembelajaran dengan berbagai strategi mengajar dan didukung pemberian bimbingan terhadap siswa dalam menyelesaikan permasalahan, serta pemberian evaluasi yang tepat.

\section{Dampak supervisi akademik model klinis terhadap peningkatan kinerja guru dalam melaksanakan proses belajar mengajar.}

Berdasarkan hasil supervisi model klinis yang ada di Gugus IV Kecamatan Sanankulon pada siklus I diperoleh keberhasilan guru dalam melaksanakan proses belajar mengajar dengan mengedepankan tugas utama guru mencapai $72 \%$ atau ada 13 guru dari 18 guru sudah berhasil dalam melaksanakan proses belajar mengajar. Hasil tersebut menunjukkan bahwa pada siklus pertama secara klasikal, guru belum berhasil. Hal ini disebabkan karena guru yang memperoleh nilai $\geq 70$ hanya sebesar $73 \%$. Pencapaian keberhasilan ini lebih kecil dari persentase ketuntasan yang dikehendaki yaitu sebesar $85 \%$.

Sedangkan pada siklus II diperoleh keberhasilan guru dalam melaksanakan proses belajar mengajar dengan mengedepankan tugas utama guru mencapai $89 \%$ atau ada 16 guru dari 18 guru sudah berhasil dalam melaksanakan proses belajar mengajar. Hasil tersebut menunjukkan bahwa pada siklus II secara klasikal, guru sudah berhasil. Hal ini disebabkan karena guru yang memperoleh nilai $\geq 70$ sudah mencapai ketentuan standarisasi yang dikehendaki yaitu $85 \%$.

Berdasarkan hasil tersebut di atas menunjukkan bahwa supervisi klinis berdampak pada peningkatan kinerja guru dalam melaksanakan proses belajar mengajar di Gugus IV Kecamatan Sanankulon Kabupaten Blitar.

\section{KESIMPULAN}

Pelaksanaan supervisi klinis dalam meningkatkan kinerja guru pada proses belajar mengajar memiliki langkah-langkah sebagai berikut: (1) Peneliti selaku pengawas sekolah berdiskusi secara terbuka dengan guru tentang masalahmasalah yang dihadapi tentang perencanaan, pelaksanaan, dan pemberian evaluasi 
dalam kegiatan proses belajar mengajar. (2) Guru melaksanakan kegiatan proses belajar mengajar dengan melakukan perencanaan, pelaksanaan, dan pemberian evaluasi pembelajaran. (3) Pengawas selaku peneliti melakukan pengamatan terhadap kegiatan guru dalam melaksanakan proses kegiatan pembelajaran. (4) Setelah kegiatan proses belajar mengajar selesai, pengawas dan guru berdiskusi tentang hasil kinerja guru dalam proses belajar mengajar untuk mengatasi kekurangan-kekurangan guru pada saat melaksanakan kegiatan proses belajar mengajar. Berdasarkan hasil supervisi model klinis yang ada di Gugus IV Kecamatan Sanankulon berdampak pada peningkatan kinerja guru dalam melaksanakan proses belajar mengajar, dimana pada siklus I diperoleh keberhasilan guru dalam melaksanakan proses belajar mengajar dengan mengedepankan tugas utama guru mencapai $72 \%$ atau ada 13 guru dari 18 guru sudah berhasil dalam melaksanakan proses belajar mengajar. Sedangkan pada siklus II diperoleh keberhasilan guru dalam melaksanakan proses belajar mengajar dengan mengedepankan tugas utama guru mencapai 89\% atau ada 16 guru dari 18 guru sudah berhasil dalam melaksanakan proses belajar mengajar.

\section{SARAN}

Hendaknya dalam merumuskan tujuan pembelajaran tidak membuat penafsiran ganda, sehingga kompetensi indikator pembelajaran dapat tercapai. Dalam menyusun RPP, hendaknya guru selalu memperhatikan alokasi waktu. Hendaknya guru selalu mengkaitkan materi dengan realitas kehidupan nyata, sehingga anak akan cepat memahami materi yang disajikan. Hendaknya guru menggunakan rubrik penilaian yang tepat dalam memberikan evaluasi.Evaluasi yang diberikan tidak menggunakan rubrik penilaian yang tepat

\section{DAFTAR RUJUKAN}

Aunurrahman, Belajar dan Pembelajaran, 2009. : Alfabeta Bandung.

Dinn Wahyudin, et.al., 2006. Pengantar Pendidikan. Jakarta : Universitas Terbuka.

Hamid Darmadi. 2009 Kemampuan Dasar Mengajar. Penerbit Alfabet Bandung.

Hani Handoko 1994. Manajemen (Edisi Kedua dan Ketiga). Yogyakarta : BPFE (Anggota IKAPI) Gadjah Mada Press

Mangkupawira, Sjafri. (2001). Manajemen Sumber Daya Manusia Strategik. Jakarta: Ghalia Indonesia.

Moeslichatoen R. 2004. Metode Pengajaran di Taman Kanak-Kanak, Jakarta : Penerbit PT. Rineka Cipta

Muhammad Ali. 1987 Guru Dalam Proses Belajar Mengajar. Penerbit Sinar Baru. Bandung

Muhibbin Syah. Psikologi Pendidikan. Bandung : Penerbit Remaja Rosdakarya.

Mulyasa, E. 2005. Menjadi Guru Profesional. PT. Remaja Rosdakarya. Bandung.

Nana Sudjana. 1990. Dasar-dasar Proses Belajar Mengajar. Bandung : Penerbit Sinar Baru Algensindo

Ngalim Purwanto (1995) Administrasi Dan Supervisi Pendidikan, Sosdakarya, Bandung

Suharsimi Arikunto. 2002. Dasar-dasar Evalusi Pendidikan. Bumi Aksara, Jakarta Thursan Hakim, 2002 , Belajar Secara Efektif, Puspa Swara, Jakarta

Tim Penyusun Kamus Pusat Pembinaan dan Pengembanga Bahasa. 1994, Kamus 
Besar Bahasa Indonesia Edisi Kedua,: PN Balai Pustaka. Jakarta.

Undang-undang Republik Indonesia Nomor 20 tahun 2003. Sistem pendidikan nasional. Jakarta: CV. Eko Jaya

Undang-Undang No.14 Tahun 2005. Guru dan Dosen. Yogyakarta: Pustaka Pelajar Offset. 